\title{
APLIKASI TEORI HIMPUNAN FUZZY DALAM PENENTUAN UKURAN PEMESANAN YANG EKONOMIS
}

\author{
Said Salim Dahdah \\ Program Studi Teknik Industri \\ Universitas Muhammadiyah Gresik \\ Email : saidsalimdh@gmail.com
}

\begin{abstract}
ABSTRAK
$\mathrm{D}$ alam dunia nyata, ketidakpastian banyak meliputi hal-hal yang berkaitan dengan proses pengambilan keputusan. Termasuk pengambilan keputusan dalam penentuan ukuran pemesanan yang ekonomis. Ketidak pastian permintaan yang sering terjadi dalam pengambilan keputusan ukuran pemesanan yang ekonomis. Ketidakpastian yang dinyatakan dalam linguistik sangat tepat jika didekati dengan bentuk fuzzy. Penentuan ukuran pemesanan yang ekonomis dalam keadaan fuzzy diselesai menggunakan aturan aritmaika fuzzy akan menghasilkan himpunan fungsi keanggotaan ukuran pemesanan dan biaya persediaan. Dengan menggunakan metode centroid untuk proses deffuzzifikasi dihasilkan ukuran pemesanan yang optimal dengan biaya persediaan yang minimal. Dalam keadaan variabel permintaan konstan didapat ukuran pemesanan yang ekonomis sebesar 300 unit dengan biaya persediaan sebesar Rp. 150.000,-. Jika variabel permintaan dalam keadaan fuzzy dengan bentuk segitiga simetris didapat ukuran pemesanan sebesar 298 unit dan biaya persediaan sebesar Rp. 150.366,- Dan peningkatan dan akan mempengaruhi penentuan ukuran pemesanan yang ekonomis dan biaya persediaan.
\end{abstract}

Kata kunci: Fuzzy, Metode Centroid, Deffuzzifikasi

\section{PENDAHULUAN}

Banyak penelitian yang menyatakan bahwa tingkat persediaan dalam perusahaan bernilai sangat besar terhadap total aset yang dipunyai perusahaan tersebut. Sehingga persediaan merupakan suatu aset yang dipunyai oleh perusahaan yang jika tidak dikelola dengan baik akan menimbulkan peningkatan biaya-biaya produksi yang tidak semestinya. Dalam hal ini manajemen persediaan yang baik memegang peranan yang penting dalam merencanakan dan mengelola persediaan dengan efektif dan efisien. Pengaruh dari manajemen persediaan yang kurang baik tidak saja mempengaruhi produksi tetapi juga akan mempengaruhi fungsi-fungsi lain dalam sistem perusahaan seperti pada finansial berpengaruh pada Return on Investment (ROI) dan likuiditas, pada fungsi pemasaran akan berpengaruh pada penjualan dan pelayanan kepada pelanggan, dan pada fungsi produksi sendiri akan berpengaruh pada efisiensi dan biaya produksi. Sebab- sebab munculnya persediaan ada beberapa hal menurut
Pujawan, baik yang telah direncanakan maupun yang tidak direncanakan. yang disebakan karena hal yang direncanakan biasanya dikarenakan adanya sesuatu yang akan diantisipasi oleh perusahaan seperti kenaikan harga, lamanya waktu pemesanan atau pengiriman. Untuk penyebab munculnya persediaan yang tidak direncanakan dikarenakan faktor yang ketidak pastian baik dari sisi luar perusahaan (permintaan, pasokan) atau dari sisi operasi Internal. Banyak metode yang digunakan untuk merencanakan dan mengelola persediaan dengan baik. Metode-metode tersebut biasanya berakaitan dengan perencanan persediaan yang mana keputusan yang akan diambil salah satunya adalah penentuan ukuran pemesanan. Keputusan ukuran pemesanan secara langsung akan berpengaruh terhadap tingkat persediaan yang ada, sehingga perlu ditentukan suatu ukuran pemesanan yang terbaik yaitu ukuran pemesanan yang dapat meminimalkan biaya persediaan dan meningkatkan service level. Biaya persediaan yang minimal dapat dihasilkan dari ukuran pemesanan yang ekonomis (Economic Order Quantity). Menurut 
Tersine untuk menentukan ukuran pemesanan yang ekonomis diperlukan data tentang permintaan, biaya persediaan dan lead time. Dengan asumsi bahwa ketiga variabel tersebut diketahui atau dapat dihitung dengan pasti. Pada kenyataannya asumsi untuk ketiga variabel tersebut sangat jarang sekali terjadi (Tersine). Banyak penelitian yang meneliti tentang ketidakpastian dari variabel tersebut. Vujosevic dkk dan Syed dkk. melakukan penelitian jika biaya persediaan yaitu biaya pesan dan biaya simpan, tidak diketahui dengan pasti. Nagoorgani dkk meneliti tentang lead time yang tidak diketahui dengan pasti. Dan beberapa penelitian yang kesemua variabelnya tidak diketahui dengan pasti sepeti pada penelitian Chiang dkk. Ketidakpastian yang melingkupi variabel tersebut dapat disebabkan karena ketidakadaan informasi, atau kurangnya informasi sehingga dapat menimbulkan ketidakjelasan, samar, atau informasi yang didapat bermakna ganda atau mungkin informasinya berupa linguistic (Zimmerman). Seperti jika ingin ditentukan permintaan produk baru atau jika perusahaan tidak mempunyai data yang cukup untuk menentukan variabel tersebut. Untuk mengatasi ketidapastian variabel yang mempunyai pola tersebut digunakan angka fuzzy untuk membantu mengatasi permasalahan tersebut sehingga memunculkan model fuzzy untuk penentuan ukuran pemesanan yang ekonomis atau yang dikenal dengan Fuzzy Economic Order Quantity. Dalam penelitian ini hanya digunakan satu variabel, variabel permintaan, yang tidak dapat diketahui dengan pasti sehingga akan dimodelkan dalam bentuk bilangan fuzzy

\section{Economic Order Quantity}

Model Penentuan pemesanan yang ekonomis klasik masih sering dikaji dalam beberapa penilitian. Selain model ini sederhana, model ini mampu untuk meminimalkan biaya persediaan. Beberapa asumsi yang digunakan dalam penggunaan model, yang berarti model ini akan dapat diimplemenatsikan dengan baik jika asumsi -asumsi tersebut terpenuhi. Salah satu asumsi tersebut adalah tingkat permintaan produk diketahui konstan dan kontinyu. Hal ini menandakan bahwa tingkat permintaan produk tersebut harus pasti. Secara grafis model ini dapat digambarkan sebagai berikut

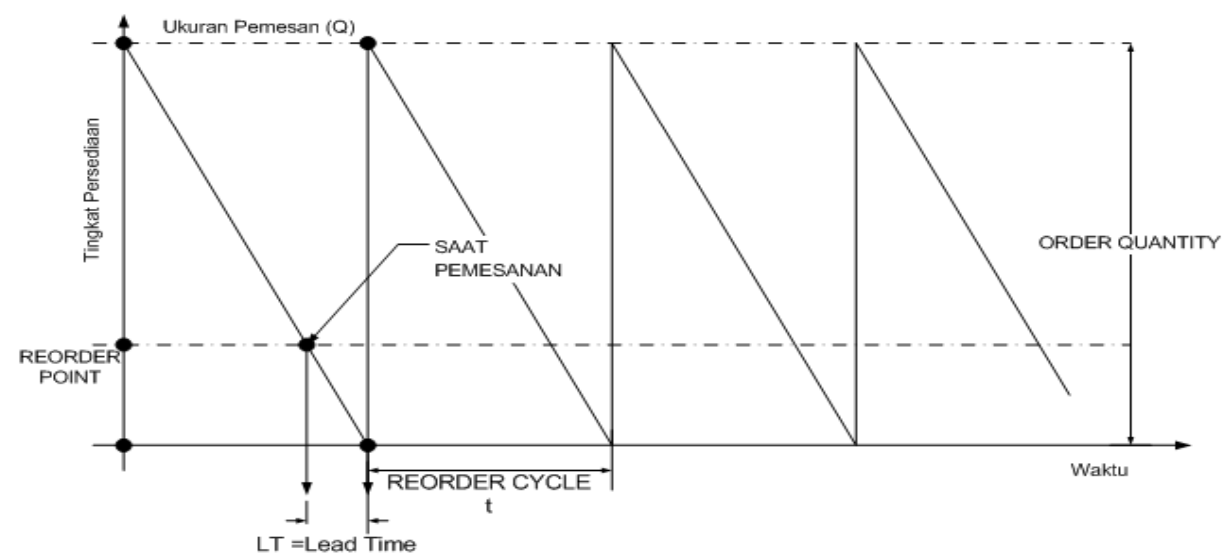

Biaya persediaan yang dihitung pada model ini adalah biaya pesan dan biaya simpan. Biaya pembelian diabaikan, dikarenakan biaya tersebut tidak bergantung pada frekuensi pemesanan (Nasution). Rumusan Biaya Persediaan adalah sebagai berikut

$$
T I C=h \cdot\left(\frac{Q}{2}\right)+c .\left(\frac{D}{Q}\right)=\sqrt{2 \cdot h \cdot c \cdot D}
$$

Dimana:

$\mathrm{h}=$ Biaya simpan per unit /satuan waktu

$\mathrm{c}=$ Biaya Pesan setiap kali pesan
$\mathrm{Q}=$ Ukuran Pemesanan
$\mathrm{D}=$ Tingkat permintaan

Ukuran pemesanan yang ekonomis adalah dengan menentukan biaya persediaan yang minimal. Rumusan biaya tersebut dapat digambarkan seperti pada tabel berikut 


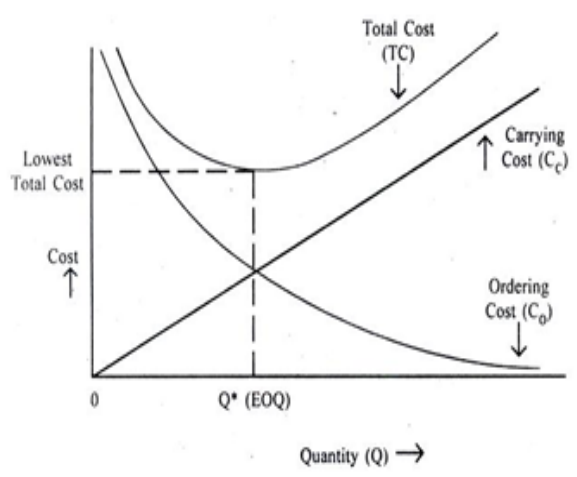

Gambar Hubungan biaya, jumlah dan biaya total

Dari gambar diatas biaya persediaan yang minimal didapat pada keadaan biaya simpan sama dengan biaya pesan. Sehingga dapat dirumuskan Ukuran pemesan yang ekonomis / Economic Order Quantity sebagai berikut

$$
E O Q=Q^{*}=\sqrt{\frac{2 c D}{h}}
$$

Dalam keadaan data permintaan tidak diketahui dengan pasti atau bersifat estimasi subjektif, perumusan penentuan ukuran pemesanan yang ekonomis dapat dimodelkan dengan Fuzzy.

\section{Fuzzy}

\section{Definisi 1.}

Sebuah himpunan fuzzy didefinisikan sebagai fungsi keanggotaan dari $\mu_{-}(\mathrm{r})^{\tilde{}}$ (r) yang mana memetakan masing-masing dan setiap elemen dari ke rentang antara 0 sampai 1 , atau dapat dituliskan dengan $\mu \_(r) \tilde{r}(r) \rightarrow[0,1]$

Dimana adalah himpunan universal.

Diartikan secara sederhana, Himpunan fuzzy adalah himpunan yang tidak mempunyai batasan secara tegas. Disisi yang lain, Sebuah himpunan fuzzy adalah himpunan yang memiliki elemen dengan karakteristik seperti pada fungsi keanggaotaan diatas.

\section{Definisi 2.}

Bilangan Fuzzy $\mathrm{r}^{\sim}$ adalah sebuah himpunan fuzzy yang didefinisikan dalam yang mempunyai tingkat keanggotaan $\mu \_(r) \tilde{\text {, dimana }} r \in R$ dengan asumsi

\section{Convex}

2. Normalized fuzzy set

3. Piecewise Continuous

Definisi 3.

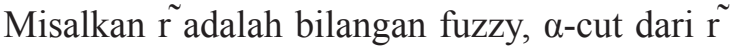
dinotasikan dengan $\tilde{\mathrm{r}} \_\tilde{\alpha}$ adalah himpunan bilangan nyata yang mana fungsi keanggotaan $\tilde{r}$ tidak lebih kecil dari $\alpha$. Dapat dituliskan dalam bentuk

$$
\tilde{r_{-}} \alpha=\left\{\mathrm{r} \mid \mu_{-}(\mathrm{r}) \tilde{\gamma}(\mathrm{r}) \geq \alpha, \mathrm{r} \in \mathrm{R}\right\}
$$

\section{Definisi 4}

Support dari satu himpunan fuzzy adalah sebuah himpunan bagian bilangan crisp (tegas) dari himpunan dasar . Dapat dituliskan dalam bentuk $\operatorname{Supp}(\tilde{\mathrm{r}})=\left\{\mathrm{r} \mid \mu \_(\mathrm{r}) \tilde{r}(\mathrm{r}) \geq 0, \mathrm{r} \in \mathrm{R}\right\}$

\section{Definisi 5}

Fungsi keanggotaan Adalah suatu kurva yang menunjukkan pemetaan nilai data input (domain) ke nilai keanggotaannya dengan cara mendakati dengan suatu bentuk fungsi. Salah satu fungsi keanggotaan (kurva) adalah triangular/segitiga (triangular fuzzy number). Bentuk kurva ini seperti pada gambar, dimana $r$ ditujukan dengan $(\mathrm{a}, \mathrm{b}, \mathrm{c})$ dimana $\mathrm{a} \leq \mathrm{b} \leq \mathrm{c}$ dan fungsi keanggotaan didefinisikan sebagi berikut :

$$
\mu_{\tilde{r}}(r)=\left\{\begin{array}{cl}
0 & x \leq a ; x \geq c \\
\frac{x-a}{b-a} & a \leq x \leq b \\
\frac{b-x}{c-b} & b \leq x \leq c
\end{array}\right.
$$

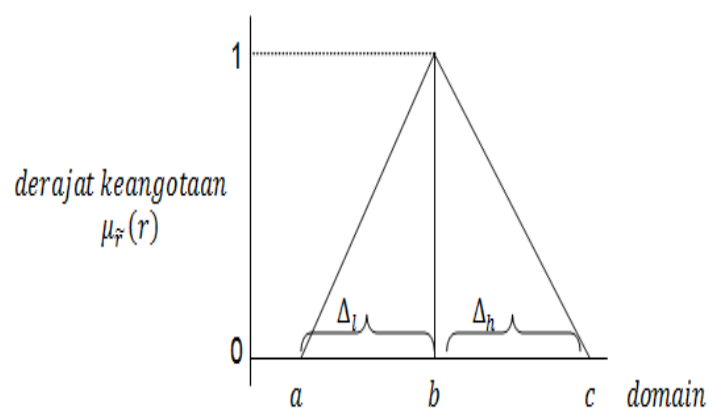

\section{Gambar 3}

dimana, a,b,c $\in \mathrm{R}$ 


\section{Definisi 5.}

Dengan menggunakan konsep definisi 3, apabila diberikan koefisien confidence $\alpha$ bilangan fuzzy segitiga akan didefinisikan sebagai himpunan dengan interval tertutup. Interval tersebut adalah

$\tilde{r_{-}} \alpha=\left(\tilde{r} \_(\alpha-L) ; \tilde{r} \_(\alpha-U)\right)=\{a+\alpha(b-a) ; c-\alpha(c-b)\}$

$\forall \alpha \in[0,1]$

\section{Definisi 6}

Proses penegasan (de-fuzzifikasi) merupakan proses keluaran dari suatu aturan-aturan fuzzy merupakan domain himpunan fuzzy yang harus dapat dirubah menjadi suatu bilangan tegas (crisp). Ada beberapa metode yang digunakan untuk proses defuzzifikasi salah satu yang didigunakan pada metode ini adalah metode pusat gravitasi (centre of gravity) atau centroid yang meruapakan metode yang paling terkenal dan efisien (Santanu Sinha dan S. P. Sarmah). Pada metode ini bilangan tegas (crisp) diambil dengan caear mengambil titik pusat daerah fuzzy. Untuk mendapatkannya, himpunan fuzzy akan diubah menjadi bilangan tegas dengan rumusan

$$
r=\text { Defuzzifikasi } \tilde{r}=\frac{\int_{R}^{2} r \cdot \mu_{\tilde{r}}(r) d r}{\int_{R} \mu_{\tilde{r}}(r) d r} .
$$

Dalam kaitan dengan penggunaan fuzzy pada penentuan ukuran pemesanan yang ekonomis, dengan variabel permintaan yang bersifat deterministik akan diubah menjadi fuzzy permintaan maka akan mengakibatkan berubahnya bentuk ukuran pemesanan yang ekonomis menjadi fuzzy ukuran pemesanan yang ekonomis $\widetilde{Q}^{*}$. Rumusan akan beruabah menjadi

$$
\widetilde{Q}^{*}=\sqrt{\frac{2 \cdot c \cdot \widetilde{D}}{h}}
$$

dimana $\mathrm{D}^{\sim}$ adalah bilangan fuzzy permintaan diasumsikan fungsi keanggotaan merepresentasikan kurva segitiga (triangular) simetris, dimana $\Delta d_{l}$ dan $\Delta d_{h}$ sama besar. Sebuah bilangan fuzzy $\tilde{\mathrm{D}}$ didefenisikan dengan support $\left[D_{l} ; D_{u}\right]$ dengan titik D_m merupakan maksimal derajat keanggotaan.

Dimana $\widetilde{D}^{-}=\left[D_{l} ; D_{m} ; D_{u}\right]$ dan $D_{l} ; D_{m} ; D_{u} \in R$, dan $D_{l}$, dimana D_m adalah batas bawah permintaan, adalah nilai tengah permintaan dan D_u adalah batas pemintaan. Derajat keanggotaan D_1 dan D_u adalah 0 dan derajat keanggotaan D_m mencapai angka 1.

Begitu halnya dengan biaya persediaan yang akan berubah menjadi

$$
\widetilde{T I C}=h \cdot \frac{Q}{2}+c \cdot \frac{\widetilde{D}}{Q}
$$

Jika ukuran pemesanan yang optimal tidak diikutkan dalam perhitungan maka didapat rumus

$$
\widetilde{T I C}=\sqrt{2 \cdot h \cdot C \cdot \widetilde{D}}
$$

\section{Contoh Numerik}

Jika diketahui biaya simpan sebesar Rp. 500/ unit/periode dan biaya pesan sebesar Rp. 22.500/ pesan. Jika permintaan tidak dapat dikehaui dengan pasti tetapi dinyatakan dengan dengan estimasi / perkiraan yang berbentuk ucapan yang bersifat subyektif seperti permintaan akan produk tersebut kira-kira 1000 unit/tahun, tetapi tidak akan kurang dari 800 unit/tahun dan tidak akan lebih dari 1200 unit/tahun. Permintaan digambarkan sebagai bilangan fuzzy yang berbentuk segitiga sehingga dapat digambarkan sebagai berikut

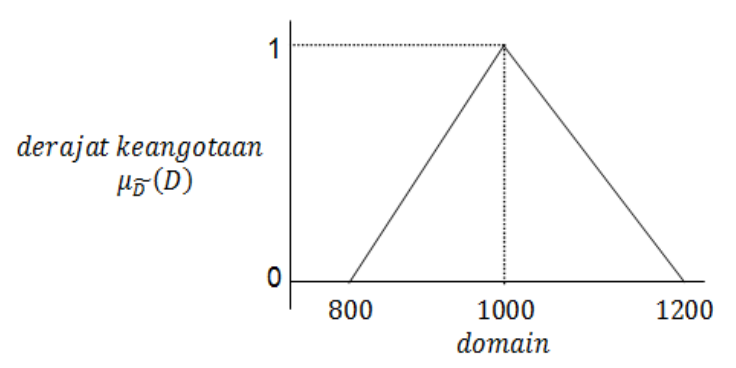

Gambar Derajat keanggotaan

Fungsi keangotaan

$$
\mu_{\widetilde{D}}(D)=\left\{\begin{array}{cc}
0 & x \leq 800 ; x \geq 1200 \\
\frac{x-D_{l}}{D_{m}-D_{l}} & 800 \leq x \leq 1000 \\
\frac{D_{m}-x}{D_{u}-D_{m}} & 1000 \leq x \leq 1200
\end{array}\right. \text {. }
$$

Dengan variabel permintaan bersifat deterministik, diasumsikan jika permintaan 1000 unit/periode, maka akan menghasilkan nilai ukuran pemesanan yang ekonomis (EOQ) jika digunakan rumus (2) adalah sebesar 300 unit. Biaya persediaan yang 
terjadi per periode dapat dihitung dengan rumus (1) sebesar Rp. 150.000.

Dengan menjadikan variabel permintaan lebih realistis yaitu dengan menjadikan permintaan tidak selalu konstan atau dalam keadaan ini adalah pemintaan tidak dapat ditentukan dengan pasti atau dengan gambaran permintaan yang bersifat linguistik seperti yang telah disebutkan diatas, maka penantuan ukuran pemesanan akan menggunakan rumus (4) dan dengan menggunakan fungsi keangotaan permintaan seperti pada (7) maka akan memunculkan fungsi keanggotaan untuk ukuran pemesanan yang ekonomis dalam bentuk fuzzy $\left(\tilde{Q}^{*}\right)$ adalah



Dengan menggunakan menggunakan rumusan (3) didapatkan hasil penegasan (defuzzifikasi) untuk ukuran pemesanan yang ekonomis (EOQ) dari fungsi keanggotaan (8) adalah 298,0412 $\approx 298$ unit.

Dengan data yang sama dapat dihitung fungsi keanggotaan untuk biaya persediaan bila variabel permintaan dalam keadaan fuzzy dengan menggunakan rumus (5) adalah sebesar 134.164,08 ; 150.000 ; 164.316,77 dengan nilai defuzzifikasi untuk biaya persediaan adalah sebesar Rp. $150.365,8891 \approx$ Rp. 150.366

Tabel 1 menampilkan perbedaan ukuran pemesanan yang ekonomis ( EOQ) dan biaya persediaan dalam keadaan variabel permintaan bersifat kontan dan fuzzy. Terlihat perbedaan nilai EOQ dan biaya persediaan antara dalam keadaan permintaan konstan dan fuzzy. Perbedaan EOQ pada keadaan variabel permintaan konstan tidak jauh berbeda dengan nilai EOQ jika pada keadaan variabel permintaan dalam keadaan fuzzy. Begitu juga dengan nilai biaya persediaan yang terpaut hanya $0.24 \%$.
Tabel 1 Perbedaan EOQ dengan Permintaan konstan dan Fuzzy

\begin{tabular}{|l|c|c|}
\hline & EOQ & Biaya persediaan \\
\hline $\begin{array}{l}\text { Variabel } \\
\text { Permintaan } \\
\text { Konstan }\end{array}$ & 300 unit & Rp. 150.000,- \\
\hline $\begin{array}{l}\text { Variabel } \\
\text { permintaan Fuzzy }\end{array}$ & 298 unit & Rp. 150.366,- \\
\hline
\end{tabular}

Analisa Sensitivitas

Pada bagian ini disajikan beberapa alternatif keadaan variabel permintaan pada kondisi fuzzy segitiga dengan keadaan dimana . Hasil perhitungan pada tabel 2 dibandingkan antara menggunakan aturan nilai titik tengah fuzzy dan menggunakan aritmika fuzzy. Terlihat bahwa dengan menggunakan perhitungan aritmatika fuzzy menghasilkan biaya persediaan yang lebih kecil jika dibandingkan dengan menggunakan aturan nilai tengah. Hanya pada pada keadaan nilai tengah permintaan 1000 unit (sama dengan kondisi awal) biaya persediaan lebih rendah dibanding dengan mengunakan aritmaika fuzzy

\section{KESIMPULAN}

Permintaan yang bersifat tidak pasti dimana ketidak pastian permintaan tersebut gambarkan dalam keadaan liguistik, sehingga penentuan ukuran pemesanan yang ekonomis dengan menggunakan model fuzzy. Hasil penentuan fuzzy ukuran pemesanan yang ekonomis lebih kecil dibandingkan dengan ukuran pemesanan yang ekonomis dengan permintaan telah diketahui dengan pasti. Pada penentuan biaya persediaan juga terlihat perbedaan antara kedua keadaan permintaan tersebut. Peningkatan nilai dan akan mempengaruhi ukuran pemesanan yang ekonomis dan biaya persediaan. Pengunaan aritmaika fuzzy lebih menghasilkan biaya persediaan yang lebih kecil dibandingkan dengan penggunaan nilai tengah. 
Tabel 2. Perbandingan Perhitungan

\begin{tabular}{|c|c|c|c|c|c|}
\hline \multirow{2}{*}{$\begin{array}{c}\text { Nilai Fuzzy } \\
\text { Permintaan }\end{array}$} & \multirow{2}{*}{$\begin{array}{c}\text { Nilai Tengah } \\
\text { Permintaan }\end{array}$} & \multicolumn{2}{|c|}{$\begin{array}{c}\text { Jika Menggunakan Nilai Tengah } \\
\text { Permintaan }\end{array}$} & \multicolumn{2}{|c|}{ Jika Menggunakan Aritmatika } \\
\cline { 3 - 6 } & $\mathrm{Q}^{*}$ & $\mathrm{TC}=\left(2^{*} \mathrm{cr}^{*} \mathrm{c}^{*} \mathrm{D}\right)^{\wedge} .5$ & $\mathrm{Q}^{*}$ & $\mathrm{TC}=\left(2^{*} \mathrm{cr}^{*} \mathrm{c}^{*} \mathrm{~m}\right)^{\wedge} .5$ \\
\hline $500-1000-1200$ & 900.00 & 284.60 & $142,302.49$ & 281.45 & $141,161.82$ \\
\hline $600-1000-1200$ & 933.33 & 289.83 & $144,913.77$ & 287.69 & $144,347.70$ \\
\hline $700-1000-1200$ & 966.67 & 294.96 & $147,478.81$ & 293.52 & $147,240.26$ \\
\hline $800-1000-1200$ & 1000.00 & 300.00 & $150,000.00$ & 298.04 & $150,365.89$ \\
\hline $800-1000-1300$ & 1033.33 & 304.96 & $152,479.51$ & 303.76 & $151,774.28$ \\
\hline $800-1000-1400$ & 1066.67 & 309.84 & $154,919.33$ & 308.15 & $154,901.33$ \\
\hline $800-1000-1500$ & 1100.00 & 314.64 & $157,321.33$ & 312.59 & $156,184.69$ \\
\hline
\end{tabular}

\section{DAFTAR PUSTAKA}

1. De P. K., Rawat Apurva, (2011) A Fuzzy Inventory Model Without Shortages Using Triangular Fuzzy Number, Fuzzy information Engineering, 1: 59-68

2. Syed J K, Aziz L A (2007) Fuzzy inventory models without using signed-distance method. Applied Mathematics and Information Sciences, 1(2): 203-209

3. Pujawan I Nyoman, (2005) Supply Chain Management, Guna Widya, Surabaya.

4. Nasution Arman Hakim, (1999), Perencanaan dan pengendalian Produksi, Guna Widya, Surabaya

5. Nagoorgani, A., Maragtham, M. (2009), (Q , r)Inventory Model with Fuzzy Lead Time, International Journal Of Algorithms, Computing And Mathematics, Vol. 2, No. 3, 85-92

6. Chiang J, Lee, H-M. Yao, J-S. (2005), Fuzzy Inventory With Backorder Defuzzification by Signed Distance Method. Journal of Information Science And Engineering, 21, 637-694

7. Nagoor Gani, A., Mohamed Assarudeen, S. N. , (2012), A New Operation on Triangular Fuzzy Number for Solving Fuzzy Linear Programming Problem, Applied Mathematical Sciences, Vol. 6, No. 11, $525-532$

8. Palash Dutta, Hrishikesh Boruah , Tazid Ali, (2011) Fuzzy Arithmetic with and without using $\alpha$-cut method: A Comparative Study,International Journal of Latest Trends in Computing (E-ISSN: 2045-5364) Volume 2, Issue 1, 99-107

9. Zimmermann,H.-J. (2000), An applicationoriented view of modeling uncertaintyEuropean Journal of Operational Research 122, $190-198$

10.Tersine, Richard. J, (1994), Principle Of Inventory And Material Management, Edisi Ke4, Prantice Hall International Inc.

11.Kusumadewi, Sri., Purnomo. Hari, (2004) Aplikasi Logika Fuzzy untuk Keputusan, Edisi Pertama, Graha Ilmu, Yogyakarta.

12.Mirko Vujosevic, Dobrila Petrovika, Radivoj Petrovikb (1996) EOQ formula when inventory cost is fuzzy, International Journal Production Economics, 45, 499-504

13.Sinha, Santanu., Sarmah, S.P., (2008), An application of fuzzy set theory for supply chain coordination, International Journal of Management Science and Engineering Management, Vol. 3 No. 1, pp. 19-32 


\title{
FLEKSIBILITAS SUPPLY CHAIN PADA PT. XYZ
}

\author{
Siti Sopiah, Evi Yuliawati \\ Jurusan Teknik Industri \\ Institut Teknologi Adhi Tama Surabaya \\ Email : evi_y_widodo@yahoo.com
}

\begin{abstract}
$\mathrm{G}$ ood Performance of Supply Chain will produce efective supply chain and finally bring individual and overall profit for the companies. The main characteristics that need to be owned by a supply chain is a infinite focus, between flexibility and efficiency. Objective of this research is to determine the level of supply chain flexibility. The first step in evaluation process is to determine the most important dimension of flexibility for the company. After that followed by determining the parameters that affect the company's supply chain flexibility for each dimension. the final step is determine the level of supply chain flexibility.

The results showed that the level of supply chain flexibility is $86.09 \%$, and the highest flexibility in the dimensions of the delivery system is achieve with a value of flexibility are $92.92 \%$, it indicates that the delivery system is very flexible because if the value near $100 \%$ it expanding the space for companies to adapt with the changes in demand.
\end{abstract}

\section{Keywords : Supply Chain Management, Flexibility Supply Chain, Dimension of Supply Chain}

\section{PENDAHULUAN}

Efisiensi menitikberatkan pada cost yang rendah dan utilitas yang tinggi (Lowest Possible Cost). Dari perspektif strategis, fleksibilitas rantai suplai memungkinkan perusahaan untuk merespon lebih cepat terhadap perubahan penawaran dan permintaan. Selain itu, perusahaan dengan rantai pasokan yang fleksibel dapat menawarkan produk baru lebih sering dengan pengembangan produk waktu singkat. Hal ini akan membantu perusahaan untuk membangun posisi kompetitif yang unggul (Swafford et, al., 2006). Sehingga dapat mengakomodasi fluktuasi yang terjadi pada komponen-komponen supply chain yaitu supplier, distributor dan customer.

Konteks supply chain tidak hanya fokus pada faktor internal perusahaan namun juga faktor eksternal perusahaan yaitu komponen-komponen lain dalam supply chain mulai dari supplier sampai dengan retailer. Untuk mencapai fleksibilitas yang tinggi, sebuah perusahaan tidak dapat berdiri sendiri tapi perlu dukungan dari semua komponen dalam supply chain perusahaan dengan fleksibilitas yang tinggi pula. Apabila tidak didukung oleh supplier dengan fleksibilitas yang tinggi maka tidak akan berhasil. Demikian pula dengan distributor dan retailernya. Apabila tidak memiliki fleksibilitas yang sebanding maka tidak akan tercapai tujuan untuk dapat mencapai kepuasan customer.

PT. XYZ merupakan perusahaan manufaktur. Perusahaan ini sangat membutuhkan fleksibilitas dari tiap komponen supply chain. Namun pada kenyataannya perusahaan ini belum mampu melakukan penerapan Supply Chain Management secara konkrit pada perusahaannya, maka sedikitnya ada masalah yang belum terdeteksi di dalam perusahaan terkait dengan masalah supply chain yang ada. Dan karena belum adanya Supply Chain Management yang konkrit, maka perusahaan ini belum mengetahui tingkat fleksibilitas dari supply chain yang ada. Oleh karena itu perlu adanya pengukuran untuk mengukur tingkat fleksibilitas supply chain guna mengetahui seberapa besar kemampuan perusahaan untuk merespon perubahan 
parameter yang terjadi.

\section{METODE}

Tujuan yang ingin dicapai dari penelitian ini adalah menentukan tingkat fleksibilitas supply chain melalui dimensi dan parameterparameter yang berpengaruh terhadap kinerja supply chain perusahaan. Untuk mendukung dan mempermudah pencapaian tujuan tersebut telah dirumuskan beberapa langkah penyelesaian. Pertama-tama dilakukan penentuan dimensi fleksibilitas supply chain yang akan diteliti. Dimensi-dimensi fleksibilitas supply chain harus mampu mencerminkan seluruh komponen tersebut. Swafford et, al (2000) menyatakan dimensidimensi fleksibilitas yang lebih umum namun dapat mencakup keseluruhan komponen dalam supply chain adalah sebagai berikut sourcing (dimensi sistem pengadaan), Product development (dimensi sistem pengembangan produk), production (dimensi sistem produksi) and delivery (dimensi sistem pengiriman). Kemudian dilanjutkan dengan menentukan parameter-parameter fleksibilitas yang relevan dengan dimensi fleksibilitas supply chain perusahaan. Selanjutnya dilakukan pengambilan data untuk menilai parameter-parameter tersebut.

Parameter-parameter yang mempengaruhi fleksibilitas supply chain PT. XYZ yang dimulai dari supplier sampai dengan customer dimunculkan, sehingga diperoleh hasil sebagai berikut :

Tabel 1 Tabel Parameter Fleksibilitas supply chain pada PT. XYZ

\begin{tabular}{|c|c|}
\hline Parameter & Dimensi Fleksibilitas \\
\hline & SISTEM PENGADAAN (SUPPLIER SYSTEM) \\
\hline & Supplier cadangan bahan penolong \\
\hline & Jumlah yang dapat dikirim oleh supplier bahan penolong \\
\hline & Sistem jadwal pengiriman supplier yang mudah \\
\hline & Memenuhi permintaan pengiriman yang mendesak \\
\hline 5 & Jangka waktu yang dijanjikan oleh supplier bahan penolong \\
\hline .6 & $\begin{array}{l}\text { Supplier menggunakan berbagai sistem transportasi } \\
\text { SISTEM PRODUKSI (PRODUUCTION SYSTEM) }\end{array}$ \\
\hline 2.1 & Menambah jumlah produksi untuk setiap produk dalam produksinva \\
\hline & Menghasilkan berbagai produk yang berbeda \\
\hline 2.3 & Menghasil kan jumlah yang sesuai permintaan \\
\hline 2.4 & Kecepatan memperbaiki mesin yang rusak \\
\hline 2.5 & Kapasitas penggunaan mesin \\
\hline$\frac{2.6}{2.7}$ & Penggunaan băhan baku yang sama dalam mesin \\
\hline & 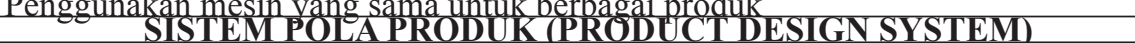 \\
\hline 3.1 & Menghasilkan dan merancang produk baru secara cepat \\
\hline 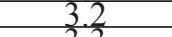 & Membuat beraneka ragam rancangan produk yang berbeda \\
\hline & Menguji material secara cepat \\
\hline 3.4 & Pengadaan material yang dibutuhkan untuk mendukung produk baru \\
\hline 3.5 & Prosedur untuk menentukan pola produk \\
\hline & \\
\hline 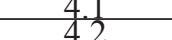 & Jumlah pengiriman yang sesuai dengan permintaan \\
\hline 4.3 & Pengagbungan produk vang berbeda dalam $1 \mathrm{kali}$ kirim \\
\hline 4.4 & engiriman permintaan yang mudah dan cepat (informasi yang mudah dan cepat) \\
\hline 4.5 & nintaan lëbih dar \\
\hline 4.6 & Perubahan rencana pengiriman \\
\hline 4.7 & Menggunakan berbagal sistem $t$ \\
\hline
\end{tabular}

Selanjutnya dilakukan pengolahan data sebagai berikut : menghitung bobot dari setiap parameter fleksibiltas dengan menggunakan metode Analytical Hierarcy Process (AHP), kemudian menghitung gap terbobot antara kebutuhan dan kemampuan fleksibilitas supply chain berdasarkan parameter yang telah ditentukan. Dan yang terakhir dilakukan pemetaan parameter-parameter yang telah disesuaikan dengan kondisi perusahaan

\section{HASIL PENELITIAN DAN PEMBAHASAN}

Pembobotan atau penentuan tingkat kepentingan dilakukan dengan menggunakan metode AHP (Analitycal Hierarcy Prosess). Secara umum hasil pembobotan bisa diinterpretasikan sebagai berikut 
Tabel 2 Tabel Tingkat Kepentingan Dimensi dan Parameter Fleksibilitas Supply Chain PT. XYZ

\begin{tabular}{|c|c|c|c|c|}
\hline Parameter & Dimensi & $\begin{array}{c}\text { Bobot } \\
\text { Dimensi }\end{array}$ & $\begin{array}{c}\text { Bobot } \\
\text { Parameter }\end{array}$ & Urutan \\
\hline SISTEM PEI & $\begin{array}{l}\text { GADAAN } \\
\text { Supplier cadangan bahan penolong }\end{array}$ & & 0.103 & 17 \\
\hline 1.2 & $\begin{array}{l}\text { Jumlah yang dapat dikirim oleh supplier } \\
\text { bahan penolong }\end{array}$ & & 0.265 & 5 \\
\hline 1.3 & $\begin{array}{l}\text { Sistem jadwal pengiriman supplier yang } \\
\text { mudah }\end{array}$ & & 0.143 & 11 \\
\hline 1.4 & $\begin{array}{l}\text { Memenuhi permintaan pengiriman } \\
\text { vang mendesak }\end{array}$ & & 0.337 & 2 \\
\hline 1.5 & $\begin{array}{l}\text { Jangka waktu yang dijanjikan oleh } \\
\text { supplier bahan penolong }\end{array}$ & & 0.089 & 18 \\
\hline 1.6 & Supplier menggunakan berbagai sistem & & 0.063 & 23 \\
\hline $\begin{array}{l}\text { SISTEM PR } \\
2.1\end{array}$ & $\begin{array}{l}\text { Menambah jumlah produksi untuk } \\
\text { setiap produk yang berbeda dalam } \\
\text { setiap produksinva. }\end{array}$ & 0.360 & 0.135 & 13 \\
\hline 2.2 & $\begin{array}{l}\text { Menghasilkan berbagai produk yang } \\
\text { berbeda }\end{array}$ & & 0.105 & 16 \\
\hline 2.3 & $\begin{array}{l}\text { Menghasilkan jumlah yang sesuai } \\
\text { dengan permintaan }\end{array}$ & & 0.396 & 1 \\
\hline 2.4 & $\begin{array}{l}\text { Kecepatan memperbaiki mesin yang } \\
\text { rusak }\end{array}$ & & 0.072 & 21 \\
\hline 2.5 & Kapasitas penggunaan mesin & & 0.058 & 24 \\
\hline 2.6 & $\begin{array}{l}\text { Penggunaan bahan baku yang sama } \\
\text { dalam mesin }\end{array}$ & & 0.167 & 10 \\
\hline 2.7 & $\begin{array}{l}\text { Penggunaan mesin yang sama untuk } \\
\text { berbagai produk }\end{array}$ & & 0.087 & 19 \\
\hline $\begin{array}{l}\text { SISTEMPO } \\
3.1\end{array}$ & $\begin{array}{l}\text { APRODUK } \\
\text { Menghasilkan dan merancang produk } \\
\text { baru secara cepat }\end{array}$ & 0.055 & 0.285 & 4 \\
\hline 3.2 & $\begin{array}{l}\text { Membuat berbagai macam rancangan } \\
\text { produk yang berbeda }\end{array}$ & & 0.184 & 8 \\
\hline $\begin{array}{l}3.3 \\
3.4\end{array}$ & $\begin{array}{l}\text { Menguji matterial secara cepat } \\
\text { Pengadaan material yang dibutuhkan } \\
\text { untuk mendukung produk baru }\end{array}$ & & $\begin{array}{l}0.136 \\
0.314\end{array}$ & 12 \\
\hline 3.5 & 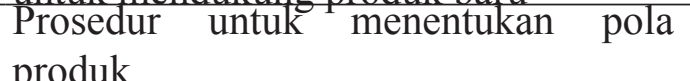 & & 0.081 & 20 \\
\hline $\begin{array}{l}\text { SISTEMTPE] } \\
4.1\end{array}$ & $\begin{array}{l}\text { GuRIMAN } \\
\text { permintaan }\end{array}$ & 0.399 & 0.299 & 6 \\
\hline$\frac{4.2}{4.3}$ & $\begin{array}{l}\text { Pengiriman produk yang beragam } \\
\text { Penggabungan produk yang berbeda } \\
\text { dalam } 1 \text { kali kirim. }\end{array}$ & & $\begin{array}{l}0.135 \\
0.117\end{array}$ & $\begin{array}{l}14 \\
15\end{array}$ \\
\hline 4.4 & $\begin{array}{l}\text { Pengiriman permintaan yang mudah } \\
\text { dan cepat (informasi yang mudah dan } \\
\text { cepat) }\end{array}$ & & 0.214 & 7 \\
\hline 4.5 & $\begin{array}{l}\text { Memenuhi permintaan lebih dari satu } \\
\text { pendistribusi }\end{array}$ & & 0.180 & 9 \\
\hline 4.6 & $\begin{array}{l}\text { Perubahan rencana pengiriman } \\
\text { Menggunakan berbagai sistem } \\
\text { transportasi }\end{array}$ & & $\begin{array}{l}0.069 \\
0.057\end{array}$ & $\frac{22}{25}$ \\
\hline
\end{tabular}

Selanjutnya dilakukan perhitungan nilai gap. Gap merupakan selisih yang terjadi antara requirement dan capability pada tiap parameter, sehingga bisa dianggap bahwa gap adalah nilai penyimpangan diantara keduanya. Nilai ideal dari gap itu sendiri adalah nol, yang berarti antara 
requirement dan capability telah terjadi kesesuaian.

Tabel 3 Tabel Gap Terbobot dan Rankingnya

\begin{tabular}{|c|c|c|c|c|}
\hline Dimensi & $\begin{array}{c}\text { Requirement } \\
\text { terbobot }\end{array}$ & $\begin{array}{l}\text { Capability } \\
\text { terbobot }\end{array}$ & $\begin{array}{l}\text { Gap } \\
\text { terbobot }\end{array}$ & Urutan \\
\hline SISTEM PENGADAAN & & & & \\
\hline $\begin{array}{l}\text { Supplier cadangan bahan penolong } \\
\text { Jumlah yang dapat dikirim oleh supplier } \\
\text { bahan penolong }\end{array}$ & $\frac{0.309}{0.883245}$ & $\frac{0.309}{0.971755}$ & $\frac{0.00}{-0.08851}$ & $\frac{12}{25}$ \\
\hline $\begin{array}{l}\text { Sistem jadwal pengiriman supplier yang } \\
\text { mudah }\end{array}$ & 0.476619 & 0.476619 & 0.00 & 13 \\
\hline $\begin{array}{l}\text { Memenuhi permintaan pengiriman yang } \\
\text { mendesak }\end{array}$ & 1.460221 & 0.898779 & 0.561442 & 2 \\
\hline $\begin{array}{l}\text { Jangka waktu yang dijanjikan oleh } \\
\text { supplier bahan penolong }\end{array}$ & 0.267 & 0.267 & 0.00 & 14 \\
\hline $\begin{array}{l}\text { Supplier menggunakan berbagai sistem } \\
\text { transportasi }\end{array}$ & 0.189 & 0.189 & 0.00 & 15 \\
\hline SISTEM PRODUKSI & & & & \\
\hline $\begin{array}{l}\text { Menambah jumlah produksi untuk } \\
\text { setiap produk yang berbeda dalam setiap } \\
\text { produksinva }\end{array}$ & 0.54 & 0.360045 & 0.179955 & 4 \\
\hline $\begin{array}{l}\text { Menghasilkan berbagai produk yang } \\
\text { berbeda }\end{array}$ & 0.42 & 0.42 & 0.00 & 16 \\
\hline $\begin{array}{l}\text { Menghasilkan jumlah yang sesuai } \\
\text { dengan permintaan }\end{array}$ & 1.848132 & 1.188 & 0.660132 & 1 \\
\hline $\begin{array}{l}\text { Kecepatan memperbaiki mesin yang } \\
\text { rusak }\end{array}$ & 0.264024 & 0.167976 & 0.096048 & 7 \\
\hline Kapasitas penggunaan mesin & 0.174 & 0.154686 & 0.019314 & 11 \\
\hline $\begin{array}{l}\text { Penggunaan bahan baku yang sama } \\
\text { dalam mesin }\end{array}$ & 0.723611 & 0.668 & 0.055611 & 9 \\
\hline $\begin{array}{l}\text { Penggunaan mesin yang sama untuk } \\
\text { berbagai produk }\end{array}$ & 0.348 & 0.348 & 0.00 & 17 \\
\hline $\begin{array}{l}\text { SISTEM POLA PRODUK } \\
\text { Menghasilkan dan merancang produk } \\
\text { baru secara cepat }\end{array}$ & 0.664905 & 0.57 & 0.094905 & 8 \\
\hline $\begin{array}{l}\text { Membuat berbagai macam rancangan } \\
\text { produk yang berbeda }\end{array}$ & 0.552 & 0.429272 & 0.122728 & 6 \\
\hline Menguji material secara cepat & 0.408 & 0.362712 & 0.045288 & 10 \\
\hline $\begin{array}{l}\text { Pengadaan material yang dibutuhkan } \\
\text { untuk mendukung produk baru }\end{array}$ & 0.837438 & 0.837438 & 0.00 & 18 \\
\hline $\begin{array}{l}\text { Prosedur untuk menentukan pola produk } \\
\text { SISTEM PENGIRIMAN }\end{array}$ & 0.216027 & 0.216027 & 0.00 & 19 \\
\hline $\begin{array}{l}\text { Jumlah pengiriman yang sesuai dengan } \\
\text { permintaan }\end{array}$ & 1.068743 & 0.916 & 0.152743 & 5 \\
\hline Pengiriman produk yang beragam & 0.54 & 0.54 & 0.00 & 20 \\
\hline $\begin{array}{l}\text { Penggabungan produk yang berbeda } \\
\text { dalam } 1 \text { kali kirim }\end{array}$ & 0.389961 & 0.429039 & -0.03907 & 24 \\
\hline $\begin{array}{l}\text { Pengiriman permintaan yang mudah dan } \\
\text { cepat (informasi yang mydah dan cepat) }\end{array}$ & 0.998738 & 0.784738 & 0.214 & 3 \\
\hline $\begin{array}{l}\text { Memenuhi permintaan lebih dari satu } \\
\text { pendistribusi }\end{array}$ & 0.66006 & 0.66006 & 0.00 & 21 \\
\hline $\begin{array}{l}\text { Perubahan rencana pengiriman } \\
\text { Menggunakan berbagai }\end{array}$ & 0.207 & 0.229977 & -0.02297 & 23 \\
\hline $\begin{array}{l}\text { transportasi } \\
\text { trat }\end{array}$ & 0.171 & 0.189981 & -0.01898 & 22 \\
\hline
\end{tabular}


Gap positif berarti nilai requirement lebih besar dibandingkan capability yang ada, berarti perlu adanya peningkatan capability pada parameter tersebut. Namun apabila nilai gap adalah negatif berarti nilai requirement lebih kecil dibandingkan capability. Berdasarkan pengolahan data ada beberapa nilai gap yang bernilai negatif yaitu sejumlah 4 parameter, ada yang bernilai 0 yaitu 10 parameter dan ada juga yang bernilai positif yaitu sejumlah 11 parameter. Dari hasil pengolahan dapat diperoleh hasil bahwa nilai rata-rata gap terbobot adalah sebesar 0.0813 nilai ini menunjukkan bahwa gap yang bernilai diatas nilai tersebut mendapatkan prioritas untuk mendapatkan perbaikan.

Tabel 4 Tabel Parameter-parameter dengan nilai gap terbobot diatas rata-rata

\begin{tabular}{|c|l|c|}
\hline Dimensi & \multicolumn{1}{|c|}{ Parameter } & Urutan \\
\hline Sistem Pengadaan & Memenuhi permintaan pengiriman yang mendesak & 2 \\
\hline \multirow{3}{*}{ Sistem Produksi } & $\begin{array}{l}\text { Menambah jumlah produksi untuk setiap produk dalam } \\
\text { produksinya } \\
\text { Menghasilkan jumlah yang sesuai permintaan }\end{array}$ & 4 \\
\cline { 2 - 3 } & Kecepatan memperbaiki mesin yang rusak & 1 \\
\hline $\begin{array}{c}\text { Sistem Pola } \\
\text { Produk }\end{array}$ & $\begin{array}{l}\text { Menghasilkap dan merancang produk baru secara cepat } \\
\text { berbeda }\end{array}$ & 8 \\
\hline \multirow{2}{*}{$\begin{array}{l}\text { Sistem } \\
\text { Pengiriman }\end{array}$} & $\begin{array}{l}\text { Jumlah pengiriman yang sesuai dengan permintaan } \\
\text { yang mudah dan cepat) }\end{array}$ & 6 \\
\hline
\end{tabular}

nilai fleksibilitas $92.92 \%$, kemudian Sistem Pola

Selanjutnya untuk menentukan tingkat fleksibilitas supply chain dibutuhkan data-data sebagai berikut

Total Requirement terbobot adalah : 14.616724

Total Capability terbobot adalah $\quad: 12.584104$

Total Gap terbobot adalah

Dan digunakan untuk menghitung tingkat fleksibilitas supply chain :

Tingkat Fleksibiltas Supply Chain adalah

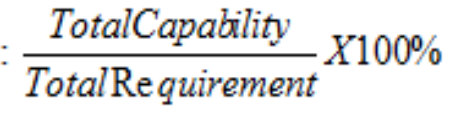

$$
: \frac{12.584104}{14.616724} X 100 \%
$$

$$
: 86.09 \%
$$

Berdasarkan nilai tingkat fleksibilitas tersebut supply chain PT. XYZ dapat dikatakan cukup fleksibel, hal ini nampak dari nilai-nilai kemampuan dan permintaan yang ada sesuai pembahasan diatas terutama berkaitan dengan kemampuan intern secara umum. Jika dikaji dari masing-masing dimensi, nilai fleksibilitas tertinggi berada pada Sistem Pengiriman (Delivery System) yaitu dengan 98
Produk (Product Design System) yaitu dengan nilai fleksibilitas 90.18\%, dan Sistem Supplier (Supplier System) yaitu dengan nilai fleksibilitas $86.81 \%$, dan paling rendah adalah Sistem Produksi (Production System) yaitu dengan nilai fleksibilitas $76.58 \%$.

\section{KESIMPULAN}

Pengukuran fleksibilitas supply chain pada PT. XYZ menunjukkan bahwa dimensi yang paling penting dan sangat berpengaruh bagi perusahaan adalah dimensi sistem pengiriman (Delivery System). Kemudian berturut-turut dimensi sistem pola produk (Product Design System), sistem pengadaan (Supplier System) dan dimensi sistem produksi (Production System). Sedangkan parameter yang memiliki nilai gap terbobot nol dan negatif serta nilai gap terbobot dibawah nilai gap terbobot rata-rata yakni 0.0813 dapat dikatakan parameter-parameter yang berpengaruh terhadap supply chain perusahaan.

Nilai fleksibilitas supply chain PT. XYZ adalah $86.09 \%$ yang artinya perusahaan dapat dianggap fleksibel, hal ini dilihat dari nilai kemampuan dan permintaan internal secara umum. Fleksibilitas tertinggi terletak pada dimensi sistem pengiriman (Delivery System) dengan nilai fleksibilitas 92.92\% ini berarti sistem pengiriman (Delivery System) perusahaan dapat beradaptasi dengan perubahan permintaan yang terjadi. 


\section{DAFTAR PUSTAKA}

[1]. Pujawan, N. (2005) Supply chain management, edisi kedua, Guna Widya, Jakarta.

[2]. Pujawan, N. (2004) "Assessing supply chain flexibility: a conceptual framework and case study”, Int. J. Integrated Supply Management, Vol. 1, No. 1, pp. 79-96.

[3]. Swafford, P., Ghosh, S. and Murthy, N. (2000) "A model of global supply chain agility and it impact on competitive performance", Proceedings of the 31st National DSI Meeting, Orlando, Florida, November 2000, pp.10371039.

[4]. Swafford, P., Ghosh, S. and Murthy, N. (2006) "The antecedents of supply chain agility of a firm: Scale development and model testing ", Journal of Operations Management, Volume 24, Issue 2, January 2006, Pages 170-188

[5]. Duclos, L.K., Lummus, R.R. and Vokurka, R.J. (2001) "A conceptual model of supply chain flexibility”, DSI 2001 Proceedings. 